state or mild malnutrition. The incidence of hyponatraemia was directly related to the degree of malnutrition. In contrast, the incidence of hypernatraemia was inversely related to the degree of malnutrition. These findings confirm our belief that moderately and severely malnourished children are more prone to develop hyponatraemic than hypernatraemic dehydration. The explanation for these findings may be that the poor reserves of electrolytes and other nutrients in malnourished children cannot compensate for accumulated losses of sodium.

In examining the relative risk of age, nutritional state, and types of dehydration for case fatality, case fatality was related to serum sodium concentrations rather than age group or nutritional state. In hyponatraemia case fatality was 10 times higher than in hypernatraemia and 2.5 times greater than in isonatraemia. Although the incidence of hyponatraemia was related to age and degree of malnutrition, case fatality was not associated with these factors. The high mortality in hyponatraemic dehydration may be due to vascular volume, which is less well preserved in hyponatraemic dehydration than in hypernatraemic or isonatraemic dehydration. This may explain the high mortality in hyponatraemic and low mortality in hypernatraemic dehydration.

Although our knowledge about the dietary patterns of these children in relation to types of dehydration is scanty, the results of this study document the high incidence and high case fatality rate of hyponatraemic dehydration. Thus in contrast to hypernatraemia, hyponatraemia is a serious complication of diarrhoea among children admitted to hospital in Bangladesh.

We are grateful to Dr W B Greenough III, director of ICDDR, B, for his critical review of the manuscript. We also thank Mrs $S$ Chowdhury and Mrs P Mahamud for secretarial work.

\section{References}

' Puffer RR, Serrano CV. Patterns of mortality in childhood: report of the inter-American investigation of mortality in childhood. Washington, DC:
Pan American Health Organisation, 1973. (Scientific publication No 262.)

James JW. Longitudinal study of the morbidity of diarrheal and respiratory infections in malnourished children. Am $\mathcal{F}$ Clin Nutr 1972;25:690-4.

${ }^{3}$ Harrison HE, Finberg L. Hypernatremic dehydration. Pediatr Clin North Am 1964;11:955-61.

${ }^{4}$ Finberg L. Hypernatremic dehydration. In: Handbook and abstracts of the international conference on infant nutrition and diarrheal disease and workshop on postgraduate pediatric education. Kuala Lumpur: Department of Pediatrics, University of Malaya, 1979:93.

Ironside AG, Tuxford AF, Heyworth B. A survey of infantile gastroenteritis. Br Med F 1970;iii:20-4.

6 Taitz LS, Byers HD. High calorie osmolar feeding and hypertonic dehydration. Arch Dis Child 1972;47:257-60.

Udani PM, Shah PM, Mukerji S, et al. Trends in the treatment of acute diarrhoeas in infancy. Indian Pediatr 1968;5:1-16.

"Wharton BA. Gastroenterological problems in children of developing countries. In: Anderson CM, Burke V, eds. Paediatric gastroenterology. Oxford: Blackwell, 1975:574.

${ }^{y}$ Garrow JS, Smith R, Ward EE. Electrolyte metabolism in severe infantile malnutrition. Oxford: Pergamon Press, 1968:50.

${ }^{0}$ Kumar V, Mohan VM, Kumar L. Fluid and electrolyte problems in acute gastroenteritis-correlation with nutritional status. Indian Pediatr $1977 ; \mathbf{1 4}: 449-53$

11 Beckett J, Mecartney J, eds. Annual report. International Centre for Diarrhoeal Disease Research, Bangladesh. Dacca: ICDDR,B, 1980.

12. Haven GT, Haven MC. Serum sodium measurement by manual and on-line dilutions. Clin Chem 1973;19:791.

13 Cash RA, Toha KMM, Nalin DR, Huq Z, Phillips RA. Acetate in the correction of acidosis secondary to diarrhoea. Lancet 1969;ii:302-3.

14 Vaughan VC III, McKay RJ, Behrman RE, eds. Nelson textbook of pediatrics. 11th ed. Philadelphia: Saunders, 1979:288-9.

15 Walker-Smith J. Diseases of the small intestine in childhood. 2nd ed. London: Pitman, 1979:217-9.

16 Gomez F, Calvan S, Frank J, Gravioto R, Chaves R, Vazquez J. Mortality in second and third degree malnutrition. 7 Trop Pediatr 1956;2:77-83.

17 Bairagi R. On validity of some anthropometric indicators as predictors of mortality. Am f Clin Nutr $1981 ; 34: 2592-4$.

18 US Department of Health, Education, and Welfare. NCHS growth curves for children: birth-18 years. Hyattsville, Md: National Center for Health Statistics, 1977. (DHEW publication No (PHS) 78-1650, series 11, No 165.)

${ }^{19}$ Khan M, Curlin GR, Chakraborty J. Growth and development studies rural Meheran Comilla. Bangladesh Medical fournal 1979;7:74-90.

(Accepted 24 November 1982)

\title{
Accuracy and value of the Hemoccult test in symptomatic patients
}

\author{
ROGER J LEICESTER, ANTONIA LIGHTFOOT, JUDITH MILLAR, DUNCAN G COLIN-JONES, \\ RICHARD H HUNT
}

\begin{abstract}
Hemoccult faecal occult blood testing is widely advocated as a screening test for colorectal cancer but few studies have shown its correlation with conventional methods of investigation for colorectal disease.
\end{abstract}

Department of Gastroenterology, Royal Naval Hospital, Haslar, Gosport, Hants PO12 2AA

ROGER J LEICESTER, FRCS, surgeon lieutenant-commander, Royal Navy consultant surgeon

ANTONIA LIGHTFOOT, research assistant

JUDITH MILLAR, MSR, research assistant

RICHARD H HUNT, FRCP, surgeon commander, Royal Navy consultant physician and gastroenterologist (now professor and head, division of gastroenterology, McMaster University, Hamilton, Ontario)

Department of Gastroenterology, Queen Alexandra's Hospital, Cosham, Portsmouth, Hants PO6 3LY

DUNCAN G COLIN-JONES, FRCP, consultant physician
In a prospective study of 802 symptomatic patients with suspected colorectal disease there was good patient compliance $(92.5 \%)$ and a high specificity for colorectal cancer $(85.4 \%)$. The false positive rate was $8.6 \%$ (12 of 140 patients with positive results), and while the test result was positive in 22 of 26 colonic cancers the false negative rate for rectal cancer $(\mathbf{4 5} \cdot 4 \%)$ should not detract from its value as a screening test if proper digital anorectal and proctosigmoidoscopic examination are widely practised.

A positive Hemoccult test result is a useful indicator for the need to proceed to full colorectal investigation, including colonoscopy.

\section{Introduction}

The Hemoccult test has been widely advocated to screen for colorectal cancer ${ }^{12}$ but no prospective studies have compared its efficacy with conventional investigation nor examined its value 
as an additional test for colorectal disease. This study was performed to compare stool occult blood testing with routine investigation using proctosigmoidoscopy and double contrast barium enema in patients with suspected colorectal disease.

\section{Methods}

We entered into the study patients with suspected colorectal disease referred to general medical and surgical clinics at two hospitals and for whom the primary investigations were proctosigmoidoscopy and double contrast barium enema. Patients were given a Hemoccult test kit with instructions to test two samples from each of three consecutive stools without dietary restriction. Testing was delayed for three days after rectal biopsy. Slides were returned to one hospital for development without rehydration. Management was conventional, but patients with normal sigmoidoscopic and barium enema appearances and a positive occult blood test result underwent colonoscopy. Our Hemoccult slides were compared for sensitivity and reproducibility with the reference standard at Memorial Sloan-Kettering Cancer Center, New York, and showed a positive result at a whole blood lysate concentration of $0.06 \mathrm{~g} \mathrm{Hb} / 1$.

\section{Results}

A total of 802 patients ( 343 male, 459 female) aged 14-89 years (mean 53) entered the study and $742(92.5 \%)$ returned slides. Of these patients, $140(18.9 \%)$ had one or more positive slides (figure).

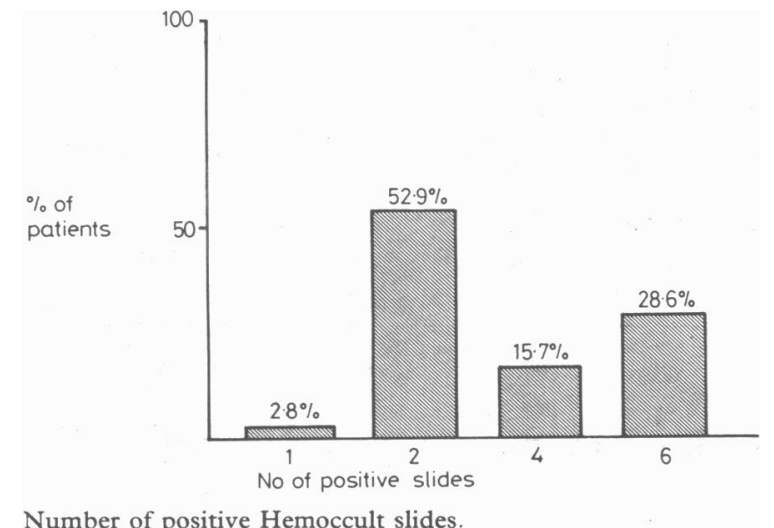

Number of positive Hemoccult slides.

Forty colorectal cancers were diagnosed in 37 patients, of whom 34 had at least one cancer detected by barium enema examination. Twenty two of the 26 patients with colonic cancer had two or more positive Hemoccult test results compared with six of 11 patients with rectal cancer. Specificity for colorectal cancer was $85.4 \%$ The table shows 1 'res' staging of the cancers. Fourteen of 34 patients with adenomatous polyps had a positive Hemoccult test result. Specificity for all colorectal neoplasia was $86.6 \%$ with a predictive value of $30 \%$.

Staging of colorectal cancers in 37 patients

\begin{tabular}{lccccc}
\hline & \multicolumn{4}{c}{ Dukes' stage } & \multirow{2}{*}{$\begin{array}{c}\text { Distant } \\
\text { metastases }\end{array}$} \\
\cline { 2 - 5 } & A & B & C & 6 \\
\hline No of patients & 4 & 16 & 11 & 6 \\
\hline
\end{tabular}

No significant disease was found in 12 patients with positive tests (false positive rate $8.6 \%$ ). Diverticular disease was detected on barium enema examination in 260 patients $(35 \%)$, and of these 41 $(15.8 \%)$ had a positive Hemoccult test result, nine of whom had an additional lesion at colonoscopy (two cancer, both Dukes' stage B; five adenomatous polyps ; one Crohn's disease ; and one angiodysplasia).

\section{Discussion}

The incidence of colorectal cancer is increasing with little $\frac{\mathbb{D}}{c}$ improvement in prognosis despite advances in surgical and $\widehat{\supset}$ diagnostic techniques. ${ }^{3}$ Important factors include the advanced $\overline{\bar{F}}$ stage of the disease at the time of diagnosis ${ }^{4}$ and the failure of $x_{0}$ sigmoidoscopy and barium enema examination to detect up to a $\Phi_{\infty}$ quarter of neoplastic lesions, as emphasised by the increasing m use of colonoscopy ${ }^{5}$ and continuing widespread use of the single $\frac{2}{2}$ contrast barium enema. ${ }^{6}$

The sensitivity of Hemoccult correlates well with colonic $\stackrel{\bar{F}}{\stackrel{9}{+}}$ cancer ( 22 out of 26 patients in our series) but less well with rectal cancer (six out of 11 patients) and adenomatous polyps $\frac{\overline{\bar{O}}}{\overline{\mathrm{T}}}$ (14 out of 34). Advantages included detecting seven neoplastic $\frac{\omega}{\vec{D}}$ lesions (two carcinoma and five polyps) in patients with positive $\stackrel{\mathbb{Q}}{\Omega}$ Hemoccult test results when barium enema detected only diverticular disease.

Though rectal bleeding is an important symptom of colorectal cancer, ${ }^{7}$ only half of our patients with carcinoma complained of $\vec{\omega}$ overt bleeding-namely, 10 of the 26 patients with colonic cancer, and nine of the 11 with rectal cancers.

The reduced correlation of Hemoccult findings with rectal lesions is explained by the limited time available for mixing of $\mathscr{O}$ blood with stool and release of haemoglobin from red cells. This $\dot{\sigma}$ should not limit the value of Hemoccult if routine examination $\mathscr{\mathscr { \sigma }}$ is properly employed, for distal lesions are often within reach of digital and sigmoidoscopic examination. Increasing combined $\omega$ use of flexible sigmoidoscopy ${ }^{8}$ will detect more proximal left 을 sided lesions, while Hemoccult gave a positive result in eight out of 10 carcinomas of the right sided or transverse colon.

Our results suggest that Hemoccult is a useful additional T investigation which when positive indicates the need to proceed $\frac{0}{2}$ to full colorectal investigation, including colonoscopy. It deserves evaluation in general practice.

We thank our colleagues who collaborated in this study, Dr Martin Fleisher, Memorial Hospital, New York, and Eaton Laboratories, Woking, Surrey, for their help and support.

Requests for reprints should be addressed to: Professor Richard $\mathrm{H}$ 亏 Hunt, Division of Gastroenterology, McMaster University, Hamilton, ㅇํㅇ Ontario, Canada.

\section{References}

1 Greegor DH. Occult blood testing for detection of asymptomatic colon cancer. Cancer 1971;28:131-4.

2 Winawer SJ. Screening for colorectal cancer. An overview. Cancer 1980; 45:1093-8.

${ }^{3}$ Gill PG, Morris PJ. The survival of patients with colorectal cancer treated in a regional hospital. Br $\mathcal{F}$ Surg 1978;65:17-20.

4 Clarke DN, Jones PF, Needham CD. Outcome in colorectal carcinoma: Oิ seven year study of population. Br Med f 1980;280:431-5. ${ }^{5}$ Swarbrick ET, Fevre DI, Hunt $\mathrm{RH}$, et al. Colonoscopy for unexplained $\mathrm{O}$

6 Theoni R, Margulis A. The state of radiographic technique in the $N$ examination of the colon: a survey. Radiol Clin North Am 1969;7:27-42. I

${ }^{7}$ Staniland JR, Ditchburn J, De Dombal FT. Clinical presentation of diseases of the large bowel: a detailed study of 642 patients. Gastroenterology 1976;70:22-8.

${ }^{8}$ Leicester RJ, Hawley PR, Pollett WG, Nicholls RJ. Flexible fibreoptic N sigmoidoscopy as an outpatient procedure. Lancet $1982 ; \mathrm{i}: 34-5$.

(Accepted 24 November 1982)

ONE HUNDRED YEARS AGO A telegram from Sierra di $\stackrel{\overparen{D}}{\stackrel{\Phi}{\Phi}}$ Falco, near Caltanisetta, in Sicily, where diphtheria is at present $\varrho$ epidemic, says that the inhabitants are in a great state of excitement, superstitiously believing-as the Milanese did during the great plague $\Omega$ three centuries ago-that the malady is being disseminated by poisoners. An unfortunate pedlar, suspected of being one of these evil-doers, has been seriously maltreated, and barely escaped with his life. (British Medical fournal 1883;i:424.) 